\title{
Chemical composition and antibacterial activity of essential oil of a Croton rhamnifolioides leaves Pax \& Hoffm
}

\section{Composição química e atividade antibacteriana do óleo essencial das folhas de Croton rhamnifolioides Pax \& Hoffm}

\author{
Ana Caroliny Vieira da Costa ${ }^{1 *}$; Geiseanny Fernandes do Amarante Melo ${ }^{1}$; \\ Marta Suely Madruga²; José Galberto Martins da Costa ${ }^{3}$; Felício Garino Junior; \\ Vicente Queiroga Neto ${ }^{4}$
}

\begin{abstract}
This study describes the chemical composition and antimicrobial activity of an essential oil from the leaves of Croton rhamnifolioides Pax\&Hoffm., an aromatic plant widely distributed in northeastern Brazil and commonly used in folk medicine. Eight components were identified: 1.8 -cineole $(46.32 \%)$ as the major compound, followed by 1 -felandreno $(16.70 \%)$, p-cymene $(10.21 \%)$, sabinene $(8.14 \%)$ and trans-caryophyllene (4.81\%). The essential oil exhibited antibacterial activity against Aeromonas hydrophila, Escherichia coli, Listeria monocytogenes, Salmonella Enteritidis and Staphylococcus aureus, with minimum inhibitory concentrations and minimum bactericidal concentrations ranging from 2.5 to 20 and 5 to $40 \mu \mathrm{L} \cdot \mathrm{mL}^{-1}$, respectively. In addition, the essential oil also affected the cellular viability of these bacteria. The results suggest the need for research to establish the potential uses of this essential oil as a natural antimicrobial in the food industry.
\end{abstract}

Key words: Croton rhamnifolioides, essential oil, antimicrobial activity, chemical composition

\section{Resumo}

O presente estudo descreve a composição química e a atividade antimicrobiana do óleo essencial das folhas de Croton rhamnifolioides Pax \& Hoffm, uma planta aromática amplamente distribuída no Nordeste do Brasil e largamente utilizada na medicina popular. Cromatografia gasosa - espectrometria de massa foi utilizada para determinar sua composição. Oito componentes foram identificados, sendo 1,8-cineol $(46,32 \%)$ o composto majoritário, seguido por 1-felandreno $(16,70 \%)$, p-cimeno $(10,21 \%)$, sabineno $(8,14 \%)$ e trans-cariofileno $(4,81 \%)$. O óleo essencial apresentou atividade antibacteriana contra Aeromonas hydrophila, Escherichia coli, Listeria monocytogenes, Salmonella Enteritidis e Staphylococcus aureus com valores de concentração inibitória mínima (CIM) e concentração bactericida mínima (CBM) entre $2,5-20 \mu \mathrm{L} / \mathrm{mL}$ e $5-40 \mu \mathrm{L} / \mathrm{mL}$, respectivamente. Além disso, o óleo essencial também afetou a viabilidade celular dessas bactérias. Os resultados sugerem a necessidade de estudos para estabelecer o uso potencial deste óleo essencial como antimicrobiano natural na indústria de alimentos.

Palavras-chave: Croton rhamnifolioides, óleo essencial, atividade antimicrobiana, composição química

\footnotetext{
${ }^{1}$ Discentes do Curso de Mestrado em Ciência e Tecnologia de Alimentos, Universidade Federal da Paraíba, UFPB, João Pessoa, PB, Brasil. E-mail: anacarolinyc@yahoo.com.br; geisy.nutri@gmail.com

${ }^{2}$ Prof $^{\mathrm{a}} \mathrm{Dr}^{\mathrm{a}}$ da UFPB, João Pessoa, PB, Brasil. E-mail: msmadruga@uol.com.br

${ }^{3}$ Prof. Dr. da Universidade Regional do Cariri, URCA, Crato, CE, Brasil. E-mail: galberto.martins@gmail.com

${ }^{4}$ Profs. Drs. da Universidade Federal de Campina Grande, UFCG, Patos, PB, Brasil. E-mail: garinofjr@hotmail.com.br; vqneto@ cstr.ufcg.edu.br

* Author for correspondence
} 


\section{Introduction}

Croton is the second largest genus in the family Euphorbiaceae and has approximately 1,300 species distributed throughout tropical and subtropical regions; with approximately 350 species, Brazil has the greatest diversity of this genus (BERRY et al., 2005). Many Croton spp. have strong economic potential due to several secondary metabolites, such as alkaloids, flavonoids and terpenoids (PAYO et al., 2001), compounds that can demonstrate therapeutic properties. Because of the relatively high content of essential oils, most Croton species are aromatic, with chemical compositions rich in monoterpenes and sesquiterpenes in addition to phenylpropanoids (SALATINO; SALATINO; NEGRI, 2007).

Croton spp. are commonly used in folk medicine for various purposes, particularly by individuals living away from major population centres. The experimentally demonstrated biological activities of these plants include anti-inflammatory (SUÁREZ et al., 2006), antiulcerogenic (ALMEIDA et al., 2003), antimicrobial (ABO; OGUNLEYE; ASHIDI, 1999), antidiabetic (OKOKON; BASSEY; OBOT, 2006), antispasmodic (PINHO-DA-SILVA et al., 2010) and antinociceptiveaction (SANTOS et al., 2005) activities.

The antimicrobial activities of essential oils have been extensively investigated due to their potential applications in the food product and pharmaceutical industries, which is of particular relevance due to the increased resistance of bacteria to antibiotics and the more common microbiological agents used in food preservation (ADAM, 2002). Thus, new antibacterial agents derived from plants could represent alternatives with molecular diversity far superior to those derived from synthetic products (OLIVEIRA et al., 2006).

Croton rhamnifolioides Pax\&Hoffm., popularly known as 'break-knife' or 'caatinga white', is an endemic species of northeastern Brazil. The plant grows as a bush or subshrub, has a pleasant aroma and is popularly used in the form of teas and infusions for the treatment of ulcers, inflammation and hypertension (RANDAU et al., 2004). As few targeted studies have evaluated the biological properties of this plant, the objective of this study was to identify the chemical composition and to evaluate antimicrobial activity of the essential oil from $C$. rhamnifolioides leaves against pathogenic bacteria of interest in the food industry.

\section{Material and Methods}

\section{Plant material}

Leaves of $C$. rhamnifolioides were collected in the rural municipality of Sumé-PB $\left(7^{\circ} 40 \mathrm{~S}, 36^{\circ} 52 \mathrm{~W}\right.$, elevation 532 m.a.s.l.), situated in the central region of Cariri Paraibano, in August-September of 2010. The material was identified at the Herbarium of the Federal University of Campina Grande, Patos, Paraíba, Brazil, and a voucher specimen of the plant deposited under registration number 691.

\section{Extraction of essential oil}

The essential oil of the fresh leaves of 'caatinga white' was obtained by hydrodistillation using a Clevenger extraction tool for a period of $2 \mathrm{~h}$. The fraction of essential oil extracted was dried with anhydrous sodium sulphate to remove the last remnants of water and stored in a hermetically sealed amber glass container at $4^{\circ} \mathrm{C}$ until the completion of the microbial and chemical analyses.

\section{Gas chromatography/mass spectrometry (GC/MS)}

The chemical composition of the essential oil was determined by GC/MS using a Shimadzu apparatus with QP2010A mass-selective detector and operating at an ionisation energy of $70 \mathrm{eV}$. The capillary column used was OV $(30 \mathrm{~m} \times 0.25$ $\mathrm{mm}$ internal diameter $\times 0.25 \mathrm{~mm}$ film) with the following specifications: temperature of $230^{\circ} \mathrm{C}$ for the injector and $290^{\circ} \mathrm{C}$ for the detector, helium as the carrier gas $\left(1.0 \mathrm{~mL} \cdot \mathrm{min}^{-1}\right)$, linear velocity of 
$47.3 \mathrm{~cm} \cdot \mathrm{s}^{-1}$, total flow rate of $24 \mathrm{~mL} \cdot \mathrm{min}^{-1}$, carrier flow rate of $24 \mathrm{~mL} \cdot \mathrm{min}^{-1}$ and pressure of $107.8 \mathrm{kPa}$. The temperature of the column commenced at $60^{\circ} \mathrm{C}$ (for $2 \mathrm{~min}$ ) and was raised to $180^{\circ} \mathrm{C}$ (for $1 \mathrm{~min}$ ) at $4^{\circ} \mathrm{C} \cdot \mathrm{min}^{-1}$ and then from 180 to $260^{\circ} \mathrm{C}$ at $10^{\circ} \mathrm{C} \cdot \mathrm{min}^{-1}$ (maintained for $10 \mathrm{~min}$ ).

The components were identified by comparing the respective mass spectra with standards recorded in the database reference library Wiley 229 and comparing the calculated retention times with the literature.

\section{Antibacterial activity}

\section{Bacterial strains}

The bacteria used to evaluate the antimicrobial activity of essential oil were Aeromonas hydrophila (INCQS 7966), Escherichia coli (ATCC 25923), Listeria monocytogenes (ATCC 7644), Staphylococcus aureus (ATCC 6538) and Salmonella Enteritidis (ATCC 1760). For the preparation of the inocula, colonies of aerobic organisms were cultivated on Muller-Hinton agar (HIMEDIA ${ }^{\circledR}$, MUMBAI, INDIA) at $35^{\circ} \mathrm{C}$ for $24 \mathrm{~h}$. The bacteria were then suspended in sterile saline solution $0.85 \%$ (w/v), and the suspension was adjusted to 0.5 on the McFarland scale to obtain standardised suspension equivalents of $10^{8}$ cfu. $\mathrm{mL}^{-1}$.

\section{Disk diffusion test}

The antibacterial activity of the $C$. rhamnifolioides essential oil was preliminarily evaluated by the diffusion technique using paper disks (WHATMAN $\mathrm{N}^{\mathrm{o}}$ 3) of $6 \mathrm{~mm}$ in diameter. A 0.1-mL aliquot of the microorganism inoculum was added to Petri dishes containing Muller-Hinton agar, and a disk of filter paper saturated with 20 $\mu \mathrm{L}$ of the essential oil was then placed in the Petri dish (BAUER; KIRBY; TURCK, 1966). The dish was incubated at $37^{\circ} \mathrm{C}$ for $24 \mathrm{~h}$, and halo formation of diameter $\geq 10 \mathrm{~mm}$, indicating microbial growth inhibition, was regarded as a positive result (SOUZA et al., 2005). The tests were performed in triplicate using gentamicin $\left(10 \mu \mathrm{g}\right.$. disc $\left.\mathrm{s}^{-1}\right)$ and tetracycline (30 $\left.\mu \mathrm{g} . \mathrm{disc}^{-1}\right)$ as positive controls and Tween 80 and distilled water as negative controls.

\section{Minimum inhibitory concentration (MIC) and minimum bactericidal concentration (MBC) determinations}

The essential oil MIC was determined using the method of macrodilution in broth. A 5-mL aliquot of $2 \times$ concentrated Muller-Hinton broth (HIMEDIA ${ }^{\circledR}$, MUMBAI, INDIA) was combined with $1 \mathrm{~mL}$ of test strain inoculum and $4 \mathrm{~mL}$ of essential oil at concentrations ranging from 0.3 to $160 \mu \mathrm{L} \cdot \mathrm{mL}^{-1}$. The mixtures were incubated for $24 \mathrm{~h}$ at $37^{\circ} \mathrm{C}$ for $L$. monocytogenes, $S$. aureus, E. coli and Salmonella Enteritidis and $28^{\circ} \mathrm{C}$ for $A$. hydrophila. At the end of the incubation period, the lowest concentration of the essential oil that prevented visible microbial growth was considered to be the MIC. Based on this, $100 \mu \mathrm{L}$ aliquots from the tubes that did not show any visible microbial growth were inoculated in test tubes containing Muller-Hinton agar slants for $24 \mathrm{~h}$ at 28 or $37^{\circ} \mathrm{C}$, as appropriate; $\mathrm{MBC}$ was considered to be the lowest concentration of essential oil that inhibited bacterial growth. Cultures without the addition of antimicrobials were used as the controls (FU et al., 2007).

\section{Effect of essential oil on the viable cell count}

The viability of bacteria under study was evaluated when exposed to different concentrations of essential oil $(\mathrm{MIC} / 2, \mathrm{MIC}$ and $\mathrm{MIC} \times 2)$ for different time intervals $(0,1,2,4,6,8,10$ and 12 h) at $37^{\circ} \mathrm{C}$ for L. monocytogenes, S. aureus, E. coli and Salmonella Enteritidis and $28^{\circ} \mathrm{C}$ for $A$. hydrophila. In the ranges established, an aliquot (1 mL) of each culture was collected and diluted in series $\left(10^{1}\right.$ to $\left.10^{5}\right)$ in $0.1 \%$ sterile peptone water and inoculated into Petri dishes containing Muller- 
Hinton agar for $24 \mathrm{~h}$ at 28 or $37^{\circ} \mathrm{C}$, as appropriate. After the incubation period, the number of viable cells was determined and expressed in $\log$ cfu. $\mathrm{mL}^{-1}$ (BARROS et al., 2009). For the experiment controls, the solution of essential oil was replaced with sterile distilled water.

\section{Statistical analysis}

The results were statistically analysed using averages, standard deviations, variance analyses and Tukey's test with a significance of $P<0.05$ using the software STATISTICA version 7.0 (STATSOFT INC, USA).

\section{Results and Discussion}

\section{Chemical composition}

The constituents identified by CG/EM, retention times and percentages are presented in Table 1. Eight substances were identified, corresponding to $100 \%$ of the total composition of oil: $65.20 \%$ were monopertenes and $34.80 \%$ sesquiterpenes. Among the compounds identified, 1.8-cineole (46.32\%) was the major compound. Other components with significant concentrations were 1-felandreno (16.70\%), p-cymene $(10.21 \%)$, sabinene $(8.14 \%)$ and trans-caryophyllene (4.81\%).

Table 1. Chemical composition of the essential oil from the leaves of Croton rhamnifolioides.

\begin{tabular}{ccc}
\hline Constituent & RT (min) & $(\%)$ \\
\hline$\alpha$-pinene & 5.15 & 8.07 \\
sabinene & 5.59 & 8.14 \\
1-felandreno & 5.90 & 16.70 \\
p-cymene & 6.11 & 10.21 \\
1.8-cineole & 6.21 & 46.32 \\
$\beta$-elemeno & 9.32 & 2.37 \\
trans-caryophyllene & 9.57 & 4.81 \\
bicyclogermacrene & 10.10 & 3.38 \\
\hline
\end{tabular}

$\mathrm{RT}=$ Retention time $(\mathrm{min})$

Source: Elaboration of the authors.

Although there are known no studies to date on the chemical composition of $C$. rhamnifolioides essential oil, the compounds identified in this study are consistent with the data for Croton spp., with the essential oils being characterised by a predominance of monoterpenes and sesquiterpenes (MECCIA et al., 2000; FONTENELLE et al., 2008).

\section{Antimicrobial activity}

The essential oil of $C$. rhamnifolioides, in absolute concentration, presented antibacterial activity against the five bacteria tested because the diameters of the zones of inhibition ranged between 13 and $21 \mathrm{~mm}$ (Table 2). The largest zone of inhibition was found for L. monocytogenes $(21 \mathrm{~mm})$, and Gram-negative E. coli and Salmonella Enteritidis showed similar zones of inhibition of $13 \mathrm{~mm}$. 
Table 2. Inhibition halos obtained for the essential oil from the leaves of Croton rhamnifolioides against pathogenic bacteria of interest in the food industry.

\begin{tabular}{ccccc}
\hline \multirow{2}{*}{ Bacterium } & \multicolumn{3}{c}{ Halo of inhibition $(\mathrm{mm}$ diameter) } \\
\cline { 2 - 5 } & Essential oil $\left(1000 \mu \mathrm{L} \cdot \mathrm{mL}^{-1}\right)$ & Gentamicin & Tetracycline & Water and Tween 80 \\
\hline S. aureus & 19 & 31 & 29 & ND \\
L. monocytogenes & 21 & 30 & 28 & ND \\
A. hydrophila & 18 & 30 & 26 & ND \\
E. coli & 13 & 36 & 21 & ND \\
S. Enteritidis & 13 & 25.2 & 19 & ND \\
\hline
\end{tabular}

$\mathrm{ND}=$ not detectable.

Source: Elaboration of the authors.

The essential oil was active against the five bacteria studied, showing MIC values that ranged 2.5-20 $\mu \mathrm{L} . \mathrm{mL}^{-1}$ (Table 3). Listeria monocytogenes exhibited the greatest in vitro sensitivity, with the lowest MIC of $2.5 \mu \mathrm{L} . \mathrm{mL}^{-1}$. Conversely, E. coli and Salmonella Enteritidis showed sensitivity to the action of the oil at a concentration of $20 \mu \mathrm{L} \cdot \mathrm{mL}^{-1}$. This lower sensitivity was also evident in their interaction with the essential oil in absolute concentration, with smaller halos of growth inhibition $(13 \mathrm{~mm})$ compared to the other strains. The MBC values of all the strains ranged from 5 to $40 \mu \mathrm{L} \cdot \mathrm{mL}^{-1}$ (Table 3 ).

Table 3. Minimum inhibitory concentration (MIC) and minimum bactericidal concentration (MBC) of the essential oil from the leaves of Croton rhamnifolioides against pathogenic bacteria of interest in the food industry.

\begin{tabular}{cccc}
\hline Tested bacterium & $\mathrm{MIC}\left(\mu \mathrm{L} \cdot \mathrm{mL}^{-1}\right)$ & $\mathrm{MBC}\left(\mu \mathrm{L} \cdot \mathrm{mL}^{-1}\right)$ & Control $^{*}$ \\
\hline S. aureus & 5 & 10 & + \\
L. monocytogenes & 2.5 & 5 & + \\
A. hydrophila & 10 & 20 & + \\
E. coli & 20 & 40 & + \\
S. Enteritidis & 20 & 40 & + \\
\hline
\end{tabular}

${ }^{*}$ Ability of bacteria to grow without the addition of the essential oil.

Source: Elaboration of the authors.

The essential oil showed a greater inhibitory activity against Gram-positive bacteria compared to other bacteria when evaluated by the methodology adopted in this study. These results may be directly related to the structure of the cell wall, considering that this is the main feature distinguishing the two bacterial groups: the outer membrane of Gram-negative strains is a barrier for certain types of antibiotics, digestive enzymes, detergents and heavy metals and could thus prevent the action of essential oils (TEPE et al., 2004). However, some authors have postulated that this relationship of cell structure and sensitivity is not well established for interactions between microorganisms and essential oils. In contrast, it has been suggested that a smaller or larger inhibitory activity of essential oils on Gram-positive or Gram-negative bacteria could be related to the particular degree of effectiveness that the individual components exert on the different types of microorganisms (DORMAN; DEANS, 2000; GUTIERREZ; BARRY-RYAN; BOURKE, 2009; KAMAZERI et al., 2012).

Rossi et al. (2011) noted that Gram-negative 
bacteria were more sensitive to action of the antimicrobial activity of $C$. lechleri essential oil. According to Cimanga et al. (2002), who evaluated the antimicrobial activity of the essential oils of various plant species (e.g., Eucalyptus globulus, Cymbopogon citratus, Ocimum americanum and Monodor amyristica), the antimicrobial activity varied with species due to the multitude and variability of chemical compounds present; however, in general, the essential oils were mainly active against Grampositive microorganisms.

The antibacterial activity of the $C$. rhamnifolioides essential oil in the present study can be attributed to the presence of such compounds as 1.8-cineol, $\alpha$-pinene, felandreno- 1 and p-cymene, which have been previously reported to possess antimicrobial properties (OKE et al., 2009; AIT-OUAZZOU et al., 2011). It is believed that monoterpene and sesquiterpene compounds, such as those found in C. rhamnifolioides essential oil, can accumulate in the bacterial membrane and cause a loss of integrity, leakage of the cytoplasmic contents, disruption of the proton motive force, lysis and cell death (BEN ARFA et al., 2006; SANTIESTEBAN-LÓPEZ; PALOU; LÓPEZMALO, 2007). Delamare et al. (2007) stated that, in addition to the presence of major compounds, antimicrobial activity is also due to the presence of other components in low concentrations that can have additive, synergistic or antagonistic interactions. Furthermore, antimicrobial activity may not be due to a specific mechanism but to various effects in the bacterial cell, including degradation of the cell wall, damage to the cytoplasmic membrane, damage to membrane proteins, leakage (loss) of the cell contents, coagulation of the cytoplasm and depletion of the proton-motive force (CARSON; MEE; RILEY, 2002), due to the numerous individual components with antimicrobial activity.

\section{Effect of oil on the viable cell count}

The effects of $C$. rhamnifolioides essential oil at different concentrations (MIC/2, MIC, MIC $\times 2$ ) on the viability of bacteria of interest in the food industry are shown in Figures 1-5. The curve of death, or the study of microbial kinetics, is a dynamic way to measure the ability of a compound to act on the viability of a microorganism. At all concentrations the essential oil reduced the number of viable cells for the five bacteria tested, as the cfu. $\mathrm{mL}^{-1}$ values were consistently lower than the controls.

The essential oil at concentrations of MIC and $\mathrm{MIC} / 2$ reduced the bacterial count from 2.8 to 1 logarithmic cycles for the initial load over the period evaluated for the bacteria tested, except for Salmonella Enteritidis. For $S$. aureus, $L$. monocytogenes and $E$. coli, there was no significant difference $(P<0.05)$ between MIC and MIC/2 at 10 $\mathrm{h}$ after contact with the essential oil. Bacteriostatic action is characterised by the effectiveness of a substance to render a bacterium unable to grow/ multiply in a liquid medium but able to be cultivated when grown on an agar medium using suitable growth conditions (SMITH-PALMER; STEWART; FYFE, 1998). The controls showed gradual growth over the ranges studied. 
Figure 1. Effect of Croton rhamnifolioides essential oil on the cellular viability of Aeromonas hydrophila: ( $\mathbf{\square})$ control $\left(0 \mu 1 . \mathrm{mL}^{-1}\right) ;(\bullet) \mathrm{MIC} / 2\left(2.5 \mu 1 . \mathrm{mL}^{-1}\right) ;(\boldsymbol{\Delta}) \mathrm{MIC}\left(5 \mu 1 . \mathrm{mL}^{-1}\right) ; \mathrm{MIC}(\boldsymbol{\nabla}) \times 2\left(10 \mu 1 . \mathrm{mL}^{-1}\right)$.

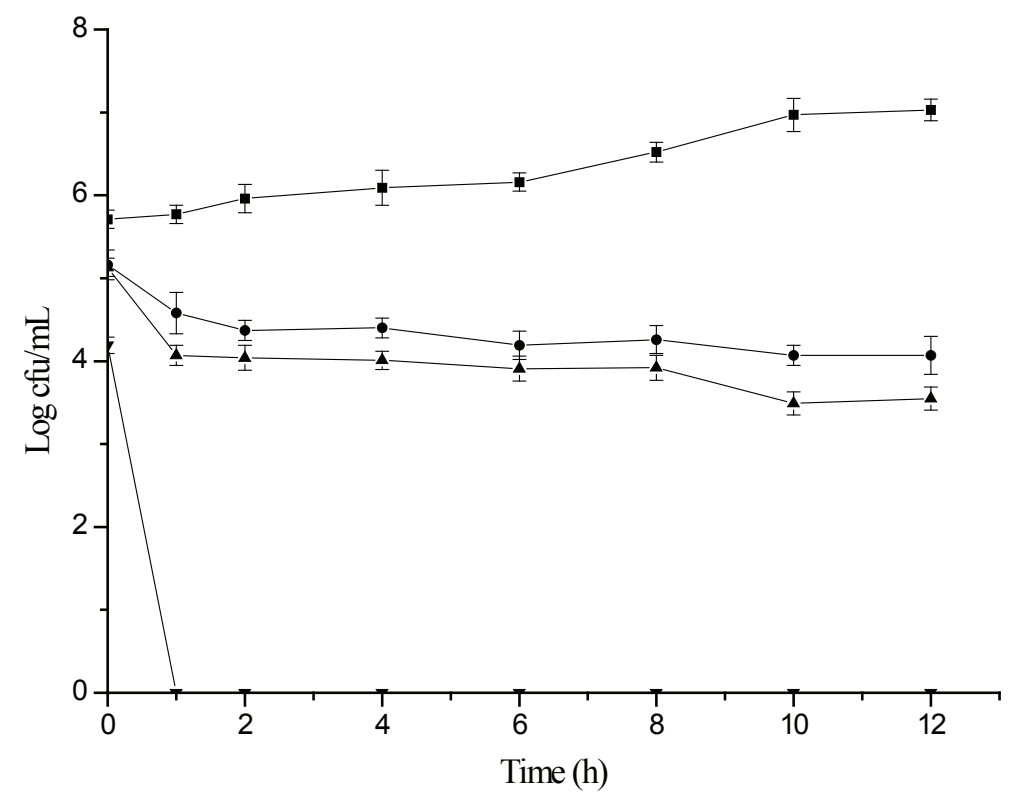

Source: Elaboration of the authors.

Figure 2. Effect of Croton rhamnifolioides essential oil on the cellular viability of Listeria monocytogenes: ( $\mathbf{\square})$ control $\left(0 \mu 1 . \mathrm{mL}^{-1}\right) ;(\bullet) \mathrm{MIC} / 2\left(1,125 \mu 1 . \mathrm{mL}^{-1}\right) ;(\boldsymbol{\Delta}) \mathrm{MIC}\left(2.5 \mu 1 . \mathrm{mL}^{-1}\right) ; \mathrm{MIC}(\boldsymbol{\nabla}) \times 2\left(5 \mu 1 . \mathrm{mL}^{-1}\right)$.

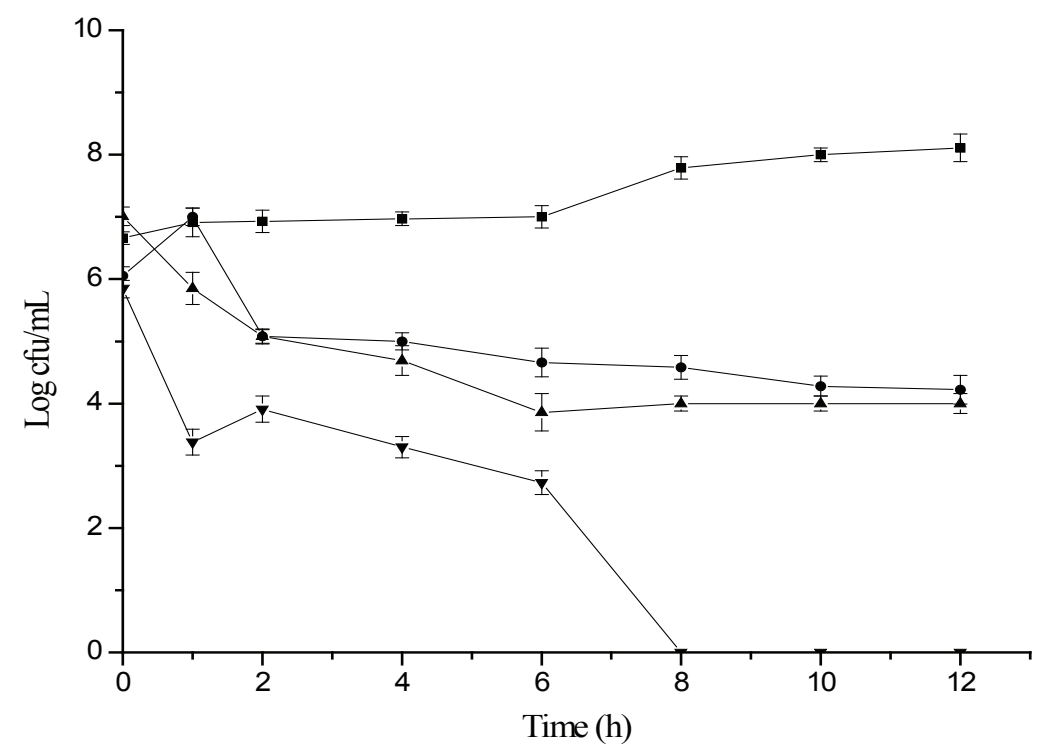

Source: Elaboration of the authors. 
Figure 3. Effect of Croton rhamnifolioides essential oil on the cellular viability of Staphylococcus aureus: ( $\mathbf{\square})$ control $\left(0 \mu 1 . \mathrm{mL}^{-1}\right) ;(\bullet) \mathrm{MIC} / 2\left(2.5 \mu 1 . \mathrm{mL}^{-1}\right) ;(\boldsymbol{\Delta}) \mathrm{MIC}\left(50 \mu 1 . \mathrm{mL}^{-1}\right) ; \mathrm{MIC}(\boldsymbol{\nabla}) \times 2\left(10 \mu 1 . \mathrm{mL}^{-1}\right)$.

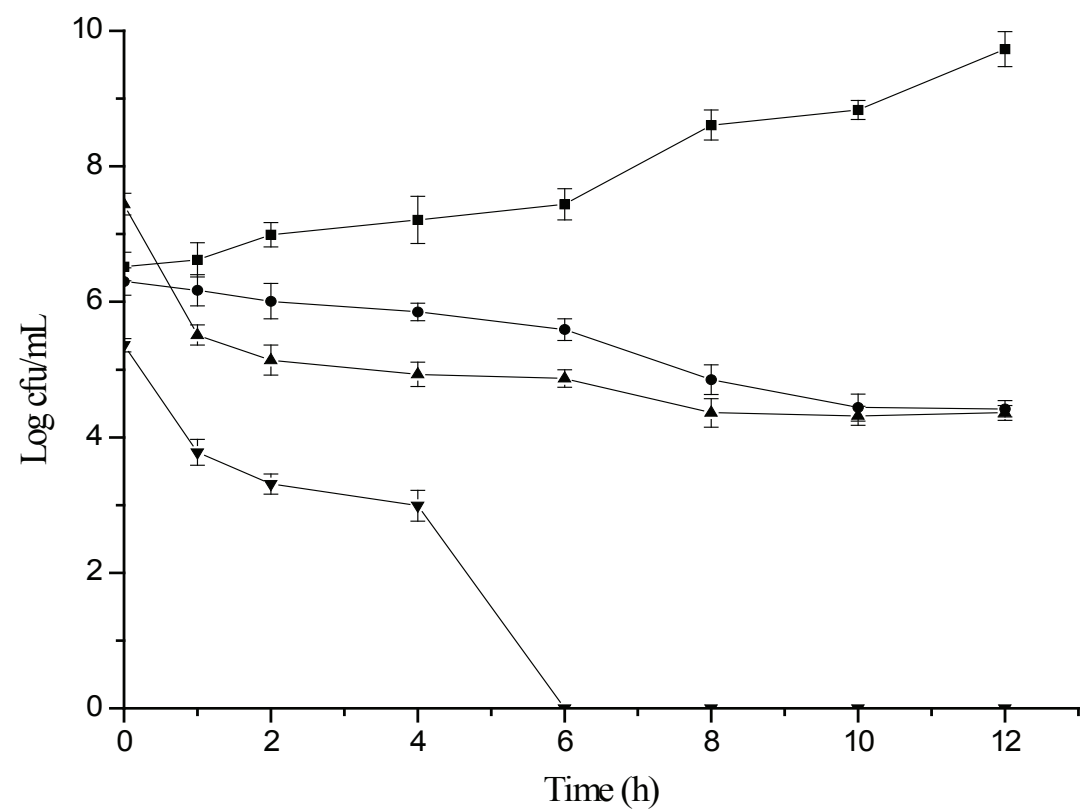

Source: Elaboration of the authors.

Figure 4. Effect of Croton rhamnifolioides essential oil on the cellular viability of Escherichia coli: ( $\mathbf{\square})$ control (0 $\left.\mu 1 . \mathrm{mL}^{-1}\right) ;(\bullet) \mathrm{MIC} / 2\left(10 \mu 1 . \mathrm{mL}^{-1}\right) ;(\boldsymbol{\Delta}) \mathrm{MIC}\left(20 \mu 1 . \mathrm{mL}^{-1}\right) ; \mathrm{MIC}(\boldsymbol{\nabla}) \times 2\left(40 \mu 1 . \mathrm{mL}^{-1}\right)$.

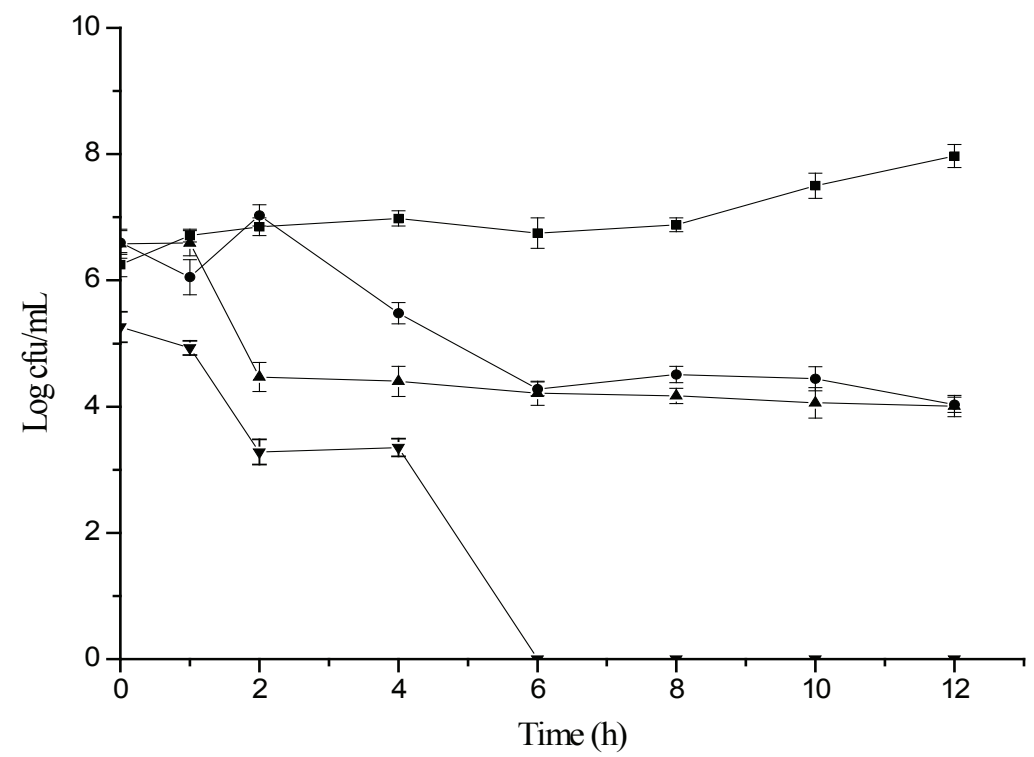

Source: Elaboration of the authors. 
Figure 5. Effect of Croton rhamnifolioides essential oil on the cellular viability of Salmonella Enteritidis: ( $\square$ ) control $\left(0 \mu 1 . \mathrm{mL}^{-1}\right) ;(\bullet) \mathrm{MIC} / 2\left(10 \mu 1 . \mathrm{mL}^{-1}\right) ;(\boldsymbol{\Delta}) \mathrm{MIC}\left(20 \mu 1 . \mathrm{mL}^{-1}\right) ; \mathrm{MIC}(\boldsymbol{\nabla}) \times 2\left(40 \mu 1 . \mathrm{mL}^{-1}\right)$.

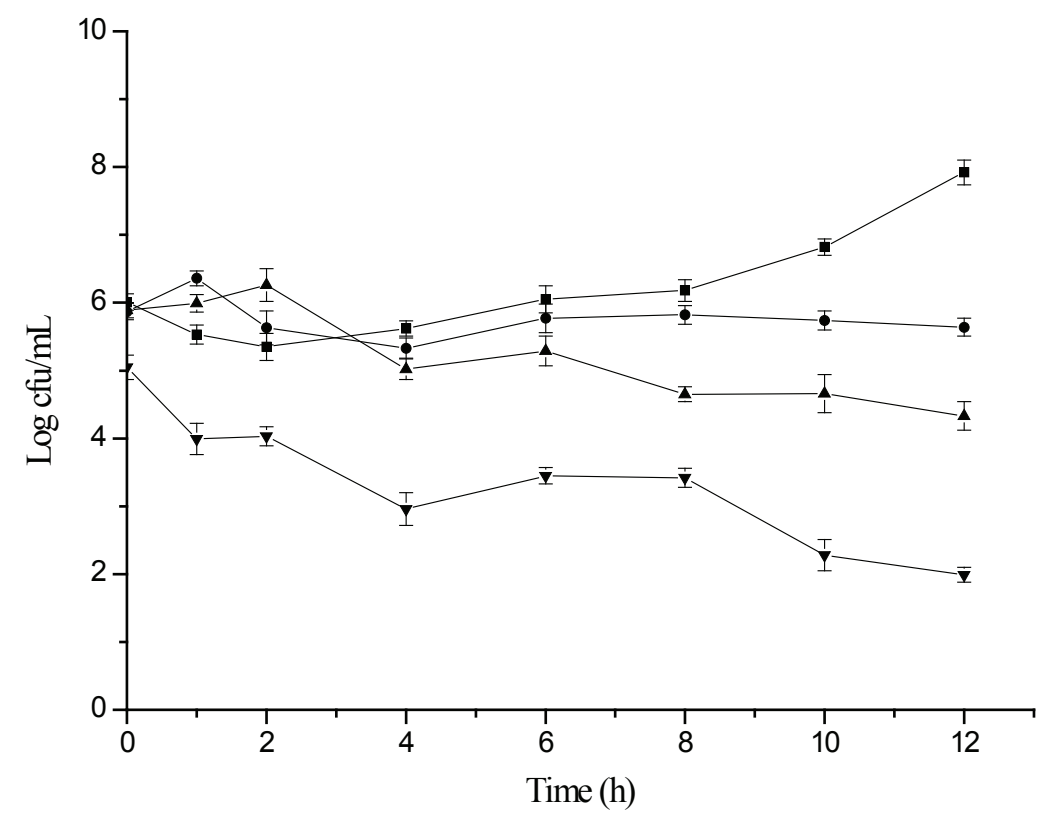

Source: Elaboration of the authors.

There was a bactericidal effect of the essential oil at a concentration of $20 \mu \mathrm{L} \cdot \mathrm{mL}^{-1}$ against $A$. hydrophila, with the reduction of four logarithmic cycles after a 1-h exposure (Figure 1). A bactericidal effect against $S$. aureus and $E$. coli was evident after $6 \mathrm{~h}$ at concentrations of 10 and $20 \mu \mathrm{L} \cdot \mathrm{mL}^{-1}$, respectively, and against $L$. monocytogenes after 8 h. Some researchers have proposed that a compound be recognised as a strong bactericide when it can cause a decrease of 1000 times (three logarithmic cycles or $99.9 \%$ ) relative to the initial inoculum (ERNST et al., 1996; LAPLANTE, 2007).

It is important tohighlight that high concentrations of the essential oil showed no bactericidal action on Salmonella Enteritidis (Figure 5) after $12 \mathrm{~h}$; however, there was a reduction in the microbial load of approximately 100 times in relation to the controls with the $20 \mu \mathrm{L} \cdot \mathrm{mL}^{-1}$ concentration. At the lowest concentration ( $\mathrm{MIC} / 2)$, the essential oil failed to consistently maintain the microbial load below the initial value of $10^{6} \mathrm{cfu} \cdot \mathrm{mL}^{-1}$. The controls showed a microbial population of approximately
$10^{8}$ cfu. $\mathrm{mL}^{-1}$, an increase of 100 times the initial inoculum, within $12 \mathrm{~h}$.

\section{Conclusion}

The results presented here demonstrate the antimicrobial activity of the essential oil derived from the leaves of $C$. rhamnifolioides and suggest the possibility of the application of the essential oil for inhibiting the growth and survival of pathogens in food. However, there is a need for detailed toxicity assessments of the essential oil and sensory attributes of the food products to identify the concentration that does not detract from the sensory characteristics yet still exerts an antimicrobial property.

\section{References}

ABO, K. A.; OGUNLEYE, V. O.; ASHIDI, J. S. Antimicrobial potential of Spondiasmombin, Croton zambesicus and Zygotritoniacrocea. Phytotherapy Research, Malden, USA, v. 13, n. 6, p. 494-497, 1999. 
ADAM, D. Global antibiotic resistance in Streptococcus pneumoniae. Journal of Antimicrobial Chemotherapy, Oxford, v. 50, n. 4, p. 1-5, 2002.

AIT-OUAZZOU, A.; CHERRAT, L.; ESPINA, L.; LARÁN, S.; ROTA, C.; PAGÁN, R. The antimicrobial activity of hydrophobic essential oil constituents acting alone or in combined processes of food preservation. Innovative Food Science \& Emerging Technologies, Wageningen, v. 12, n. 3, p. 320-390, 2011.

ALMEIDA, A. B. A.; MELO, P. S.; LIMA, C. A. H.; GRACIOSO, J. S.; CARLI, L.; NUNES, D. S.; HAUN, M.; BRITO, A. R. M. Antiulcerogenic effect and cytotoxic activity of semi-synthetic croton in obtained from.Croton cajucara Benth. European Journal of Pharmacology, Amsterdam, v. 472, n. 11, p. 205-212, 2003.

BARROS, J. C.; CONCEIÇÃO, M. L.; GOMES NETO, N. J.; COSTA, A. C. V.; SIQUEIRA JÚNIOR, J. P.; BASÍLIO JÚNIOR, I. D.; SOUZA, E. L. Interference of Origanumvulgare L. essential oil on the growth and some physiological characteristics of Staphylococcus aureusstrains isolated from foods. LWT-Food Science and Technology, Alemanha, v. 42, n. 6, p. 1139-1143, 2009.

BAUER, A. W. M.; KIRBY, J. C.; TURCK, M. Antibiotic susceptibility testing by a standardized single disk method. American Journal of Clinical Pathology, Salt Lake, v. 45, n. 3, p. 493-496, 1966.

BEN ARFA, A.; COMBES, S.; PREZIOSI-BELLOY, L.; GONTARD, N.; CHALIER, P. Antimicrobial activity of carvacrol related to its chemical structure. Letters in Applied Microbiology, Malden, v. 43, n. 2, p. 149-154, 2006.

BERRY, P. E.; HIPP, A. L.; WURDACK, K. L.; VAN, E. E.; RIINA, R. Molecular phylogenetics of the giant genus Croton and tribe Crotoneae (Euphorbiaceaesensustricto) using ITS and trnL-trnF sequence data. American Journal of Botany, St. Louis, v. 92, n. 9, p. 1520-1534, 2005.

CARSON, C. F.; MEE, B. J.; RILEY, T. V. Mechanism of action of Melaleucaalternifolia(tea tree) oil on Staphylococcus aureus determined by time-kill, lysis, leakage and salt tolerance assays and electron microscopy. Antimicrobial Agents and Chemotherapy, Washington, v. 46, n. 6, p. 1914-1920, 2002.

CIMANGA, K.; KAMBU, K.; TONA, L.; APERS, S.; BRUYNE, T.; DEHERMANS, N.; TOTTÉ, J.; PIETERS, L.; VLIETINCK, A. J. Correlation between chemical composition and antibacterial activity of essential oils of some aromatic medicinal plants growing in the Democratic Republic of Congo. Journal of Ethnopharmacology, Limerick, v. 79, n. 2, p. 213-220, 2002.
DELAMARE, A. P. L.; MOSCHEN-PISTORELO, I. V.; ARTICO, L.; ATTI-SERAFINI, L.; ECHEVERRIGARY, S. Antibacterial activity of the essential oils of Salvia officinalis L. and Salvia triloba L. cultivated in South Brazil. Food Chemistry, Barking, v. 100, n. 2, p. 603608, 2007.

DORMAN, H. J. D.; DEANS, S. G. Antimicrobial agents from plants: antibacterial activity of plant volatile oils. Journal of Applied Microbiology, Oxford, v. 88, n. 2, p. 308-316, 2000.

ERNST, M. E.; KLEPSER, E. J.; WOLFE, E. J.; PFALLER, M. A. Antifungal dynamics of LY 303366, an investigation echinocandin B analog, against Candida spp. Diagnostic in Microbial Infectious Diseases, Iowa, v. 26, n. 3, p. 125-131, 1996.

FONTENELLE, R. O. S.; MORAIS, S. M.; BRITO, E. H. S.; BRILHANTE, R. S. N.; CORDEIRO, R. A.; NASCIMENTO, N. R. F. Antifungal activity of essentialoils of Crotonspecies fromthe Brazilian Caatinga biome. Journal of Applied Microbiology, Oxford, v. 104, n. 5, p. 1383-1390, 2008.

FU, Y.; ZU, Y. G.; CHEN, L. Y.; SHI, X. G.; WANG, Z.; SUN, S. Antimicrobial activity of clove and rosemary essential oils alone and in combination. Phytotherapy Research, London, v. 21, n. 10, p. 989-994, 2007.

GUTIERREZ, J.; BARRY-RYAN， C.; BOURKE, P. The antimicrobial efficacy of plant essential oil combinations and interactions with food ingredients. Food Microbiology, Summit-Argo, v. 26, n. 2, p. 142150, 2009.

KAMAZERI, T. A.; SAMAH, O. A. B.; SUSANT, D.; QARALLEH, H. Antimicrobial activity and essential oils of Curcuma aeruginosa, Curcuma mangga, and Zingiber cassumunar from Malaysia. Asian Pacific Journal of Tropical Medicine, Singapore, v. 5, n. 3, p. 202-209, 2012.

LAPLANTE, K. L. In vitro activity of lysostaphin, mupirocin, and tea tree oil against clinical methicillinresistant Staphylococcus aureus. Diagnostic in Microbiology and Infectious Diseases, Iowa, v. 57, n. 4, p. 413-418, 2007.

MECCIA, G.; ROJAS, L. B.; ROSQUETE, C.; SAN FELECIANO, A. Essential oil of croton ovalifolius Vahl from Venezuela. Journal Flavour Fragrance, Ichihara, v. 15, n. 3, p. 144-146, 2000.

OKE, F.; ASLIM, B.; OZTURK, S.; ALTUNDAG, S. Essential oil composition, antimicrobial and antioxidant activities of Saturejacuneifolia Ten. Food Chemistry, Barking, v. 112, n. 4, p. 874-879, 2009. 
OKOKON, J.; BASSEY, A.; OBOT, J. Antidiabetic activity of ethanolic leaf extract of croton zambesicus Muell. (thunder plant) in alloxan diabetic rats. African Journal of Traditional, Complementary and Alternative Medicine, New York, v. 3, n. 2, p. 21-26, 2006.

OLIVEIRA, D. R.; LEITÃO, G. G.; SANTOS, S. S.; BIZZO, H. R.; LOPES, D.; ALVIANO, C. S.; ALVIANO, D. S.; LEITÃO, S. G. Ethnopharmacological study of two Lippiaspecies from Oriximina, Brazil. Journal of Ethnopharmacology, Limerick, v. 108, n. 1, p. 103-108, 2006.

PAYO, H. A.; DOMINICIS, M. E.; MAYOR, J.; OQUENDO, M.; SARDUY, R. Tamizaje fitoquímico preliminar de espécies del género Cróton L. Revista Cubana de Farmacia, Habana, v. 35, n. 3, p. 203-206, 2001.

PINHO-DA-SILVA, P. L.; MAIA, P. V.; GARCIA, T. M.; CRUZ, J. S.; MORAIS, S. M.; SOUZA, A. N.; LAHLOU, S.; CARDOSO, J. H. Croton sonderianus essential oil samples distinctly affect rat airway smooth muscle. Phytomedicine, Stuttgart, v. 17, n. 10, p. 721$725,2010$.

RANDAU, K. P.; FLORÊNCIO, D. C.; FERREIRA, C. P.; XAVIER, H. S. Pharmacognostic study of Croton rhamnifolius H.B.K. and Croton rhamnifolioides Pax \& Hoffm. (Euphorbiaceae). Brazilian Journal of Pharmacognosy, João Pessoa, v. 14, n. 2, p. 89-96, 2004.

ROSSI, D.; GUERRINI, A.; MAIETTI, S.; BRUNI, R.; PAGANETTO, G.; POLI, F.; SCALVENZI, L.; RADICE, M.; SARO, K.; SACCHETTI, G. Chemical finger print ingand bioactivity of Amazonian Ecuador Crotonlechleri Müll. Arg. (Euphorbiaceae) stem bark essential oil: a new functional food ingredient? Food Chemistry, Barking, v. 126, n. 3, p. 837-848, 2001.
SALATINO, A.; SALATINO, M. L. F.; NEGRI, G. Traditional uses, chemistry and pharmacology of Croton species (Euphorbiaceae). Journal of the Brazilian Chemical Society, Curitiba, v. 18, n. 1, p. 11-33, 2007.

SANTIESTEBAN-LÓPEZ, A.; PALOU, E.; LÓPEZMALO, A. Susceptibility of food-borne bacteria to binary combinations of antimicrobials at selected aw and pH. Journal of Applied Microbiology, Singapore, v. 102, n. 2, p. 486-497, 2007.

SANTOS, F. A.; JEFERSON, F. A.; SANTOS, C. C.; SILVEIRA, E. R.; RAO, V. S. Antinociceptive effect of leaf essential oil from Croton sonderianus in mice. Life Science, Union, v. 77, n. 23, p. 2953-2963, 2005.

SMITH-PALMER, A.; STEWART, J.; FYFE, L. Antimicrobial properties of plant essential oils and essences against five important food-borne pathogens. Letters in Food Microbiology, v. 26, n. 1, p. 118-122, 1998.

SOUZA, E. L.; STAMFORD, T. L. M.; LIMA, E. O.; TRAJANO, V. N.; FILHO, J. M. B. Antimicrobial effectiveness of spices: an approach for use in food conservation systems. Brazilian Archives of Biology and Technology, Curitiba, v. 48, n. 4, p. 549-558, 2005.

STATSOFT, Inc. STATISTICA. data analysis software system, version7.0. USA, 2004.

SUÁREZ, A. I.; BLANCO, B.; COMPAGNONE, R. S.; SALAZAR-BOOKAMAN, M. M.; ZAPATA, V.; ALVARADO, C. Anti-inflammatory activity of Croton cuneatus aqueous extract. Journal of Ethnopharmacology, Limerick, v. 105, n. 1, p. 99-101, 2006.

TEPE, B.; DONMEZ, E.; UNLU, M.; CANDAN, F.; DAFERERA, D., POLISSIOU, M.; SOKMEN, A. Antimicrobial and antioxidative activities of the essential oils and methanol extracts of Salvia cryptantha (Montbret et Aucher ex Benth.) and Salvia multicaulis (Vahl). Food Chemistry, Barking, v. 84, n. 4, p. 519-525, 2004. 
